\title{
Piperine as a phytogenic additive in broiler diets
}

\author{
Verônica da Silva Cardoso(1), Cristina Amorim Ribeiro de Lima(2), Marco Edílson Freire de Lima( ${ }^{(3)}$, \\ Luis Eduardo Gomes Dorneles ${ }^{(3)}$ and Maria das Graças Miranda Danelli(1)
}

\begin{abstract}
(1)Universidade Federal Rural do Rio de Janeiro (UFRRJ), Instituto de Veterinária, Rodovia BR 465, Km 07, CEP 23890-000 Seropédica, RJ, Brazil. E-mail: verocardoso@yahoo.com.br, danelli@ufrrj.br (2)UFRRJ, Instituto de Zootecnia. E-mail: cribilima@terra.com.br (3)UFRRJ, Instituto de Ciências Exatas. E-mail: marco@ufrrj.br, legdorneles@hotmail.com
\end{abstract}

\begin{abstract}
The objective of this work was to determine the effect of piperine as a phytogenic additive in chicken broiler diet. Seven-day-old male chicks were randomly allocated in four experimental treatments $(\mathrm{n}=24)$, with four replicates $(n=6)$. The piperine was added to diets at concentrations of $0,60,120$, and $180 \mathrm{mg} \mathrm{kg}^{-1}$ for 35 consecutive days. The following were evaluated: biochemical, hematological and histopathological parameters; performance and carcass yield. Histomorphometric analyses were also carried out. The addition of 120 and $180 \mathrm{mg} \mathrm{kg}^{-1}$ of piperine did not alter broiler body weight and feed conversion, whereas $60 \mathrm{mg} \mathrm{kg}^{-1}$ of piperine interfered positively in both parameters from 36 to 42 days of age and significantly increased the absorption surface of the duodenum and the ileum. No macroscopic alteration in organ size and color was observed in the broilers fed diets with the evaluated concentrations of piperine. The supplementation of 120 and $180 \mathrm{mg} \mathrm{kg}^{-1}$ of piperine is toxic to liver tissue and reduces the absorption surface of the jejune. The diet supplemented with $60 \mathrm{mg} \mathrm{kg}^{-1}$ of piperine is safe.
\end{abstract}

Index terms: Piper nigrum, performance, phytogenic additive, sanitation.

\section{Piperina como suplemento fitogênico na dieta de frangos de corte}

\begin{abstract}
Resumo - O objetivo deste trabalho foi determinar o efeito da piperina, como suplemento fitogênico, na dieta de frangos de corte. Pintos com sete dias de idade foram distribuídos aleatoriamente em quatro tratamentos $(\mathrm{n}=24)$, com quatro repetições $(n=6)$. A piperina foi adicionada na ração nas concentrações de $0,60,120$ e $180 \mathrm{mg} \mathrm{kg}^{-1}$ por 35 dias consecutivos. Foram avaliados: parâmetros bioquímicos, hematológicos e histopatológicos; desempenho e rendimento de carcaça. Também foram realizadas análises histomorfométricas. A adição de 120 e $180 \mathrm{mg} \mathrm{kg}^{-1}$ de piperina não alterou o peso corpóreo e a conversão alimentar dos frangos, enquanto $60 \mathrm{mg} \mathrm{kg}^{-1}$ de piperina interferiram positivamente em ambos os parâmetros, de 36 a 42 dias de idade, e aumentaram significativamente a superfície de absorção do duodeno e do íleo. Não foi observada alteração macroscópica no tamanho e na coloração dos órgãos dos frangos alimentados com as rações com as concentrações de piperina avaliadas. A suplementação com 120 e $180 \mathrm{mg} \mathrm{kg}^{-1}$ de piperina é tóxica ao tecido hepático e reduz a superfície de absorção do jejuno. A dieta suplementada como $60 \mathrm{mg} \mathrm{kg}^{-1}$ de piperina é segura.
\end{abstract}

Termos para indexação: Piper nigrum, desempenho, aditivo fitogênico, sanidade.

\section{Introduction}

The practice of using antimicrobial feed additives, such as antibiotics and chemotherapy drugs, as growth promoters was banned in livestock and poultry diets in 2006 by the European Union (Castanon, 2007). Therefore, a worldwide search for equally effective alternatives, without negative impacts on animal welfare and consumer health, was initiated. Herbal extracts, spices, and some of their components (phytogenic additives) are possible natural alternatives to the use of antibiotics as growth promoters in broiler diets. Phytogenic feed additives are plant-derived products used in animal feeding to improve the performance of agricultural livestock and may satisfy the increasing concerns of consumers, since they prove to be safe and effective. Phytogenics may also minimize the serious environmental problem of bacterial resistance caused by the use of antibiotics as growth promoter additives (Perić et al., 2009). Phytogenics can improve the consumption and conversion of food, and the digestibility and weight gain of broiler chickens. However, the action mechanisms of these additives is not yet clear (Perić et al., 2009; Scheuermann et al., 2009). Studies on the application of phytogenics in broiler nutrition show inconsistent - positive or 
negative - results on broiler performance (Botsoglou et al., 2002; Ertas et al., 2005; Cross et al., 2007; Ocak et al., 2008).

Piperine (1-piperoyl-piperidine) is a major alkaloid component of black (Piper nigrum Linn.) and long (Piper longum Linn.) pepper, and is responsible for their pungent and biting taste (Dogra et al., 2004). These pepper species have been used as seasoning in cookery and as an ingredient in alternative medicine for the treatment of several illnesses, such as bronchitis and asthma (Singh, 1992). Among its chemical-biological activities, piperine exhibits antimicrobial (Reddy et al., 2004), anti-inflammatory (Pradeep \& Kuttan, 2004) and antioxidant (Mittal \& Gupta, 2000) properties. It also increases the bioavailability of certain drugs in the organism (Karan et al., 1999) and acts as a chemopreventive factor against pro-carcinogens activated by cytochrome P-450 (Reen et al., 1997).

According to Kohlert et al. (2000), the active principles of phytogenic additives are absorbed in the intestine by enterocytes and are quickly metabolized by the body. Piperine induces alterations in membrane dynamics and permeation characteristics, as well as the synthesis of proteins associated with cytoskeletal function, resulting in an increase in the small intestine absorptive surface (Khajuria et al., 2002). The administration of piperine by gavage $\left(170 \mathrm{mg} \mathrm{kg}^{-1}\right.$ of body weight) or intraperitoneally ( $85 \mathrm{mg} \mathrm{kg}^{-1}$ of body weight) to male albino rats was efficiently absorbed (about 97\%), and its passage through the intestine indicated that the highest concentration in stomach and small intestine occurred at approximately 6 hours. Only traces (less than $0.15 \%$ ) were detected in the serum, kidney, and spleen from 30 min to 24 hours (Bhat \& Chandrasekhara, 1986). The rapid metabolism and the short-life of piperine indicate a low risk of accumulation in the tissue. Cardoso et al. (2009), while working with broiler chickens, found that orally administered piperine did not interfere on weight gain or liver relative weight. However, liver histopathological changes were observed in a dose-dependent manner, indicating that $1.12 \mathrm{mg} \mathrm{kg}^{-1}$ of piperine, with oral route of administration, is nontoxic for broiler chickens, as previously reported for rats and mice (Dogra et al., 2004; Gagini et al., 2010).

Besides being a natural compound that does not produce detected residues in the animal or in their derived products, piperine is easily isolated in great amounts and has shown interesting biological effects in studies developed in mammals.

The objective of this work was to determine the effect of piperine as a phytogenic additive in chicken broiler diet.

\section{Materials and Methods}

The experiment was carried out in 2010 at the Universidade Federal Rural do Rio de Janeiro (UFRRJ), RJ, Brazil. The piperine was obtained according to Ikan (1991), in 5-7\% yield and 98\% purity, determined by gas chromatography-mass spectrometry (GC-MS), with melting point of $128-129^{\circ} \mathrm{C}$ and spectrometric data (1:00 and 13C NMR for infrared spectroscopy and MS) similar to that reported in the literature (Araújo-Júnior et al., 1997; Siddiqui et al., 1997). The piperine was incorporated in the diets at concentrations of $0,60,120$, and $180 \mathrm{mg} \mathrm{kg}^{-1}$. A vertical mixer with a $500-\mathrm{kg}$ capacity was used for the homogenization of the feed treatments, and mixing was done $15 \mathrm{~min}$ after the last ingredient was added. Micronutrients were premixed, and the different concentrations of piperine were incorporated to the basal diet instead of a fixed amount of the inert material, without altering the composition of the diet. The concentrations were determined in a previous study on the bioavailability of orally administered piperine (Cardoso et al., 2009).

The experiment was approved by the Research Ethics Committee of the UFRRJ and was carried out with 96 one-day-old male Cobb chicks housed in an experimental shed. At seven days of age, with the intestine able to metabolize fat-soluble substances, such as piperine, the chicks were randomly allocated to four experimental treatments, with four replicates of six chicks each, in a completely randomized design. The treatments used were: non-supplemented control diet, and diet supplemented with 60,120 , and $180 \mathrm{mg} \mathrm{kg}^{-1}$ of piperine. The diets (Table 1) were made based on nutrient requirement recommendations (Rostagno et al., 2005), and food and water were provided ad libitum. The chicks were kept in a standard environmental condition with natural light. The corn used in the diets was sent to the Mycotoxicology Laboratory of the Veterinary Institute of the UFRRJ for mycotoxin analysis. The treatments were administrated for 35 consecutive days, and the broilers were weighed and slaughtered at end of the experiment according to 
the rules established by the Ministério da Agricultura Pecuária e Abastecimento.

The following production indexes were determined at inicial (8-21 days), growing (22-35 days), final (2642 days) and total period (8-42 days of age): feed intake, weight gain and feed conversion ratie. Mortality, body weight and carcass yield at 42 days of age.

For hematological tests, the blood was collected with EDTA from the wing vein of 12 randomly selected broilers from each treatment. Red blood cells, white blood cells, and hematocrit were determined according to Jain (1993). The hemoglobin concentration was measured by the method of oxyhemoglobin (Campbell \& Dein, 1984), and total plasmatic protein was determined by refractometry (Coles, 1984). The mean corpuscular volume and the mean corpuscular hemoglobin concentration were calculated according to Wintrobe (1934).

For biochemical tests, the blood was collected without EDTA from the wing vein of 12 randomly selected broilers from each treatment. Urea, creatinine,

Table 1. Composition and nutritional values of chicken broiler diets.

\begin{tabular}{|c|c|c|c|}
\hline Ingredient (kg) & $8-21$ days & $22-35$ days & $36-42$ days \\
\hline Corn & 60.73 & 65.38 & 68.85 \\
\hline Soybean meal & 33.92 & 29.92 & 25.925 \\
\hline Soybean oil & 1.603 & 1.85 & 1.85 \\
\hline Dicalcium phosphate & 1.763 & 1.884 & 1.457 \\
\hline Limestone & 0.82 & 0.78 & 0.745 \\
\hline Salt & 0.447 & 0.425 & 0.4 \\
\hline Choline chloride & 0.04 & 0.04 & 0.04 \\
\hline DL-Methionine & 0.223 & 0.227 & 0.213 \\
\hline L-Lysine & 0.177 & 0.227 & 0.265 \\
\hline L-Threonine & 0.037 & 0.052 & 0.063 \\
\hline Vitamin supplement ${ }^{(1)}$ & 0.1 & 0.052 & 0.05 \\
\hline Mineral supplement ${ }^{(2)}$ & 0.05 & 0.1 & 0.1 \\
\hline Coccidiostatic $^{(3)}$ & 0.05 & 0.05 & - \\
\hline Starch (inert material) & 0.03 & 0.03 & 0.040 \\
\hline Piperine & - & - & - \\
\hline Total & 100 & 100 & 100 \\
\hline \multicolumn{4}{|l|}{ Calculated value (\%) } \\
\hline Crude protein & 20.65 & 19.1 & 17.74 \\
\hline Metabolizable energy $\left(\mathrm{kcal} \mathrm{kg}^{-1}\right)$ & 2,980 & 3,050 & 3,100 \\
\hline Methionine & 0.5453 & 0.5257 & 0.4964 \\
\hline Methionine/Cystine & 0.871 & 0.833 & 0.788 \\
\hline Calcium & 0.878 & 0.81 & 0.751 \\
\hline Available phosphorus & 0.439 & 0.405 & 0.374 \\
\hline$\underline{\text { Sodium }}$ & 0.213 & 0.201 & 0.191 \\
\hline \multicolumn{4}{|c|}{$\begin{array}{l}{ }^{(1)} \text { Composition per } \mathrm{kg} \text { of product: } 7,500 \mathrm{UI} \text { of vitamin } \mathrm{A} ; 2,500 \mathrm{UI} \text { of } \\
\text { vitamin D3; } 18,000 \mathrm{mg} \text { of vitamin E; } 1,200 \mathrm{mg} \text { of vitamin } \mathrm{K} 3 ; 1,500 \mathrm{mg} \text { of } \\
\text { vitamin B1; 5,500 mg of vitamin B2; 2,000 mg of vitamin B6; } 12,500 \mathrm{mcg} \\
\text { of vitamin B12; } 67 \mathrm{mg} \text { of biotin; } 10 \mathrm{~g} \text { of pantothenic acid; } 35 \mathrm{~g} \text { of nicotinic } \\
\text { acid. }{ }^{(2)} \mathrm{Composition} \text { per kg of product: } 120 \mathrm{~g} \text { of } \mathrm{Mn} ; 13 \mathrm{~g} \text { of Cu; } 60 \mathrm{~g} \text { of Fe; } \\
100 \mathrm{~g} \text { of } \mathrm{Zn} ; 2,500 \mathrm{mg} \text { of I; } 500 \mathrm{mg} \text { of Se. }{ }^{(3)} 5.0 \mathrm{~g} \text { of semduramicin. }\end{array}$} \\
\hline
\end{tabular}

aspartate transaminase (AST), alanine transaminase (ALT), and gamma glutamyl transpeptidase (GGT), from the serum, were analyzed using a commercial kit (Bioclin S.A., Belo Horizonte, MG, Brazil).

For histopathological analysis, the proventriculus, gizzard, liver, small intestine, and kidney from six broilers of each treatment were analyzed. The tissues were fixed in $10 \%$ neutral buffered formalin solution and embedded in paraffin wax. All histological analyses were performed on 5.0- $\mu \mathrm{m}$ sections (four cross-sections for each sample), mounted on slides, and stained with haematoxylin and eosin.

The histomorphometric analysis of the small intestine was performed with four randomly selected broilers from each treatment. The whole small intestine and some samples from the duodenum, the jejune, and the ileum were collected, and the slides were prepared as previously described. The histomorphometric examination (villi height and width, as well as crypt depth) was performed by light microscopy, and the measurement was done using a public domain image analysis software (ImageJ, National Institute of Mental Health, Bethesda, MD, USA). The results were obtained from the average of ten adjacent villi.

All values were expressed as mean \pm standard deviation. Means were compared by the analysis of variance, followed by the Kruskal Wallis or the Student-Newman-Keuls test, at $5 \%$ probability. The software package GraphPad Prism 5.0 was used for statistical analysis.

\section{Results and Discussion}

Piperine did not promote significant effects in the production indexes in the initial and growing periods. In the final period, from 36 to 42 days of age, the broilers receiving the diet supplemented with $60 \mathrm{mg} \mathrm{kg}^{-1}$ of piperine showed better weight gain and feed conversion rate, at 5\% probability. However, this was not reflected in the total period (Table 2). The supplementation of piperine in broiler diets does not cause any loss in production parameters, which can be improved in the final period.

The highest concentration of piperine $\left(180 \mathrm{mg} \mathrm{kg}^{-1}\right)$ significantly reduced the total number of leukocytes (Table 3). In this treatment, there was a decrease of heterophils in comparison to the control. Broiler chickens fed diet supplemented with piperine showed significant decrease of monocytes with dose-dependent 
characteristics. However, 60 and $120 \mathrm{mg} \mathrm{kg}^{-1}$ of piperine did not decrease white blood cell count. When performing hematological analyses of mice, Dogra et al. (2004) found that concentrations of piperine (2.25 and $4.5 \mathrm{mg} \mathrm{kg}^{-1}$ ) caused a significant reduction in total leukocyte counts; in the differential leukocyte count, there was an increase in the percentage of neutrophils. Piperine at $120 \mathrm{mg} \mathrm{kg}^{-1}$ significantly decreased the mean corpuscular hemoglobin concentration, when compared to the other treatments and the control. No significant differences were observed among treatments as to the other evaluated parameters.

Table 2. Production indexes of chicken broiler fed diets supplemented with different concentrations of piperine during each growth phase and the entire experimental period ${ }^{(1)}$.

\begin{tabular}{|c|c|c|c|c|c|}
\hline \multirow[t]{2}{*}{ Parameter } & \multicolumn{4}{|c|}{ Piperine $\left(\mathrm{mg} \mathrm{kg}^{-1}\right)$} & \multirow{2}{*}{$\begin{array}{l}\mathrm{CV} \\
(\%)\end{array}$} \\
\hline & 0 & 60 & 120 & 180 & \\
\hline & \multicolumn{5}{|c|}{$8-21$ days } \\
\hline Feed intake $(\mathrm{g})$ & $1,020 \pm 30.92 \mathrm{a}$ & $1,036 \pm 8.70 \mathrm{a}$ & $976.00 \pm 40.44 \mathrm{a}$ & $970.40 \pm 22.67 \mathrm{a}$ & 1.84 \\
\hline Weight gain (g) & $700.10 \pm 39.53 \mathrm{a}$ & $668.50 \pm 35.30 \mathrm{a}$ & $662.50 \pm 23.50 \mathrm{a}$ & $655.20 \pm 14.41 \mathrm{a}$ & 4.17 \\
\hline \multirow[t]{2}{*}{ Feed conversion rate } & $1.50 \pm 0.10 \mathrm{a}$ & $1.59 \pm 0.10 \mathrm{a}$ & $1.49 \pm 0.05 \mathrm{a}$ & $1.51 \pm 0.08 \mathrm{a}$ & 3.54 \\
\hline & \multicolumn{5}{|c|}{$22-35$ days } \\
\hline Feed intake $(\mathrm{g})$ & $2,138 \pm 219.70 \mathrm{a}$ & $2,029 \pm 139.10 \mathrm{a}$ & $2,103 \pm 203.50 \mathrm{a}$ & $2,027 \pm 1,690 \mathrm{a}$ & 8.77 \\
\hline Weight gain (g) & $1,213 \pm 39.46 a$ & $1,166 \pm 64.37 \mathrm{a}$ & $1,174 \pm 73.55 \mathrm{a}$ & $1,187 \pm 71.86 \mathrm{a}$ & 5.27 \\
\hline \multirow[t]{2}{*}{ Feed conversion rate } & $1.76 \pm 0.16 \mathrm{a}$ & $1.74 \pm 0.10 \mathrm{a}$ & $1.80 \pm 0.26 \mathrm{a}$ & $1.71 \pm 0.08 \mathrm{a}$ & 8.31 \\
\hline & \multicolumn{5}{|c|}{ 36-42 days } \\
\hline Feed intake $(\mathrm{g})$ & $1,543 \pm 99.82 \mathrm{a}$ & $1,458 \pm 102.80 \mathrm{a}$ & $1,456 \pm 113.50 \mathrm{a}$ & $1,476 \pm 105.00 \mathrm{a}$ & 7.11 \\
\hline Weight gain (g) & $674.60 \pm 107.70 \mathrm{a}$ & $829.30 \pm 73.32 b$ & $699.20 \pm 34.24 \mathrm{a}$ & $688.30 \pm 59.04 a$ & 9.57 \\
\hline \multirow[t]{2}{*}{ Feed conversion rate } & $2.32 \pm 0.25 \mathrm{a}$ & $1.77 \pm 0.165 \mathrm{~b}$ & $2.09 \pm 0.204 \mathrm{a}$ & $2.15 \pm 0.08 \mathrm{a}$ & 8.40 \\
\hline & \multicolumn{5}{|c|}{$8-42$ days } \\
\hline Feed intake $(\mathrm{g})$ & $4,701 \pm 275.30 \mathrm{a}$ & $4,525 \pm 196.00 \mathrm{a}$ & $4,535 \pm 76.58 \mathrm{a}$ & $4,473 \pm 239.10 \mathrm{a}$ & 4.31 \\
\hline Weight gain (g) & $2,587 \pm 136.30 \mathrm{a}$ & $2,663 \pm 105.10 \mathrm{a}$ & $2,536 \pm 93.44 a$ & $2,531 \pm 127.30 \mathrm{a}$ & 4.48 \\
\hline Feed conversion rate & $1.82 \pm 0.05 \mathrm{a}$ & $1.70 \pm 0.08 \mathrm{a}$ & $1.79 \pm 0.09 \mathrm{a}$ & $1.77 \pm 0.06 \mathrm{a}$ & 3.85 \\
\hline Mortality & 0 & 0 & 0 & 0 & \\
\hline Body weight (kg) & $2.83 \pm 0.20 \mathrm{a}$ & $2.82 \pm 0.19 \mathrm{a}$ & $2.80 \pm 0.19 \mathrm{a}$ & $2.77 \pm 0.26 \mathrm{a}$ & 7.50 \\
\hline Carcass yield $(\%)$ & $71.88 \pm 3.96 \mathrm{a}$ & $72.11 \pm 2.31 \mathrm{a}$ & $73.42 \pm 3.17 \mathrm{a}$ & $72.47 \pm 2.29 \mathrm{a}$ & 4.05 \\
\hline
\end{tabular}

${ }^{(1)}$ Means \pm standard deviation followed by equal letters do not differ by the Student-Newman-Keuls test, at $5 \%$ probability.

Table 3. Hematological and biochemistry parameters of chicken broiler fed diets supplemented with different concentrations of piperine ${ }^{(1)}$.

\begin{tabular}{|c|c|c|c|c|c|}
\hline \multirow[t]{2}{*}{ Parameter } & \multicolumn{4}{|c|}{ Piperine $\left(\mathrm{mg} \mathrm{kg}^{-1}\right)$} & \multirow{2}{*}{$\begin{array}{l}\text { CV } \\
(\%)\end{array}$} \\
\hline & 0 & 60 & 120 & 180 & \\
\hline Red blood cell $\times 10^{6} \mu \mathrm{L}^{-1}$ & $2.68 \pm 0.36 \mathrm{a}$ & $2.81 \pm 0.31 \mathrm{a}$ & $3.04 \pm 0.38 \mathrm{a}$ & $2.83 \pm 0.38 \mathrm{a}$ & 12.59 \\
\hline Hematocrit $(\%)$ & $30.17 \pm 2.86 a$ & $30.17 \pm 3.01 \mathrm{a}$ & $30.50 \pm 2.32 \mathrm{a}$ & $30.33 \pm 2.64 a$ & 7.90 \\
\hline Hemoglobin $\left(\mathrm{g} \mathrm{dL}^{-1}\right)$ & $9.10 \pm 0.65 \mathrm{a}$ & $9.73 \pm 0.90 \mathrm{ab}$ & $8.78 \pm 0,71 \mathrm{ac}$ & $9.18 \pm 0.61 \mathrm{abc}$ & 7.79 \\
\hline Mean corpuscular volume (fL) & $114.40 \pm 17.80 \mathrm{a}$ & $108.40 \pm 14.56 \mathrm{a}$ & $101.50 \pm 11.09 \mathrm{a}$ & $108.00 \pm 10.20 \mathrm{a}$ & 12.36 \\
\hline Mean corpuscular hemoglobin $\left(\mathrm{gm} \mathrm{dL}^{-1}\right)$ & $30.33 \pm 2.70 \mathrm{a}$ & $32.47 \pm 3.96 \mathrm{a}$ & $28.90 \pm 2.85 b$ & $30.41 \pm 2.34 \mathrm{a}$ & 9.67 \\
\hline Total plasmatic protein $\left(\mathrm{g} \mathrm{dL}^{-1}\right)$ & $3.42 \pm 0.25 \mathrm{a}$ & $3.48 \pm 0.30 \mathrm{a}$ & $3.53 \pm 0.27 \mathrm{a}$ & $3.48 \pm 0.28 \mathrm{a}$ & 7.90 \\
\hline White blood cell $\times 10^{3} \mu \mathrm{L}^{-1}$ & $31.08 \pm 5.57 \mathrm{a}$ & $29.75 \pm 4.77 \mathrm{a}$ & $28.17 \pm 5.29 \mathrm{a}$ & $25.92 \pm 3.37 \mathrm{~b}$ & 16.43 \\
\hline Lymphocytes x $10^{3} \mu \mathrm{L}^{-1}$ & $16.77 \pm 2.20 \mathrm{a}$ & $18.89 \pm 3.50 \mathrm{a}$ & $17.33 \pm 3.50 \mathrm{a}$ & $17.13 \pm 2.89 \mathrm{a}$ & 17.17 \\
\hline Heterophils $\times 10^{3} \mu \mathrm{L}^{-1}$ & $10.60 \pm 3.40 \mathrm{a}$ & $9.12 \pm 1.57 \mathrm{ab}$ & $9.02 \pm 2.59 \mathrm{ab}$ & $7.27 \pm 1.81 \mathrm{~b}$ & 25.72 \\
\hline Monocytes $x 10^{3} \mu \mathrm{L}^{-1}$ & $2.53 \pm 1.13 \mathrm{a}$ & $1.77 \pm 0.75 b$ & $1.69 \pm 0.60 \mathrm{~b}$ & $1.45 \pm 0.31 b$ & 30.69 \\
\hline Eosinophil $\times 10^{3} \mu \mathrm{L}^{-1}$ & $0.42 \pm 0.13 \mathrm{a}$ & $0.24 \pm 0.07 \mathrm{a}$ & $0.40 \pm 0.10 \mathrm{a}$ & $0.27 \pm 0.04 \mathrm{a}$ & 26.05 \\
\hline Aspartate aminotransferase $\left(\mathrm{U} \mathrm{L}^{-1}\right)$ & $200.40 \pm 91.07 \mathrm{a}$ & $227.60 \pm 70.37 \mathrm{a}$ & $286.80 \pm 81.85 b$ & $265.80 \pm 83.93 b$ & 34.11 \\
\hline Alanine aminotransferase $\left(\mathrm{U} \mathrm{L}^{-1}\right)$ & $38.17 \pm 13.98 \mathrm{a}$ & $49.42 \pm 14.54 \mathrm{a}$ & $45.83 \pm 13.58 \mathrm{a}$ & $40.33 \pm 11.52 \mathrm{a}$ & 31.06 \\
\hline Gama glutamiltransferase $\left(\mathrm{U} \mathrm{L}^{-1}\right)$ & $12.83 \pm 4.90 \mathrm{a}$ & $15.00 \pm 3.08 \mathrm{a}$ & $13.75 \pm 3.34 \mathrm{a}$ & $13.58 \pm 3.63 a$ & 27.41 \\
\hline Urea $\left(\mathrm{mg} \mathrm{dL}^{-1}\right)$ & $5.27 \pm 1.42 \mathrm{a}$ & $5.00 \pm 1.54 \mathrm{a}$ & $4.90 \pm 2.18 \mathrm{a}$ & $4.27 \pm 1.68 \mathrm{a}$ & 35.36 \\
\hline Creatinine $\left(\mathrm{mg} \mathrm{dL}^{-1}\right)$ & $0.50 \pm 0.11 \mathrm{a}$ & $0.45 \pm 0.09 \mathrm{a}$ & $0.47 \pm 0.10 \mathrm{a}$ & $0.49 \pm 0.11 \mathrm{a}$ & 20.84 \\
\hline
\end{tabular}

${ }^{(1)}$ Means \pm standard deviation $(\mathrm{n}=12)$ followed by equal letters do not differ by the Student-Newman-Keuls and the Kruskall-Wallis test (for monocytes and eosinophils), at 5\% probability. 
At the concentrations of 120 and $180 \mathrm{mg} \mathrm{kg}^{-1}$, piperine increased AST, indicating hepatocyte lesions due to alterations in cellular membrane permeability (Kaneko, 1989). The activity of AST is considered a sensitive, but not specific, marker of hepatocyte disorder in most bird species (Schmidt et al., 2007). The other hepatic enzymes and renal function were in the normal range for broiler chickens and did not vary among the treatments (Table 3 ).

To investigate whether piperine is able to modify the ultrastructure of small intestinal epithelium, increasing its absorption surface, histomorphometric analyses of the duodenum, the jejune, and the ileum were carried out (Table 4).

The effect of piperine was not homogeneous on the intestinal mucosa. Dietary supplementation of piperine for 35 days influenced the measurements of segments of the small intestinal villi. Piperine $\left(60 \mathrm{mg} \mathrm{kg}^{-1}\right)$ increased the area (height $\mathrm{x}$ width) of the villi in the duodenum and the ileum, as well as the absorption surface in these segments of the small intestine (Table 4). The treatments 120 and $180 \mathrm{mg} \mathrm{kg}^{-1}$ of piperine reduced the absorption surface of the jejune. There was no modification in the duodenum and the ileum, except for the treatment with $120 \mathrm{mg} \mathrm{kg}^{-1}$ of piperine in the ileum segment. There was a reduction in crypt depth in the duodenum and the jejune in all concentrations of piperine, when compared to the control. However, the same was not observed in the ileum.
Khajuria et al. (2002) related piperine $\left(10 \mathrm{mg} \mathrm{kg}^{-1}\right.$ of body weight) to alterations in membrane dynamics and permeation characteristics, and to the induction in the synthesis of proteins associated with cytoskeleton function, which increased the small intestine absorptive surface, in a time-dependent manner, up to 2 hours in rats.

The gastrointestinal system is affected by black pepper and piperine, which have a definite effect on intestinal motility, anti-diarrhea property, and on the ultrastructure of intestinal villi, improving the absorbability of nutrients (Takaki et al., 1990; Bajad et al., 2001). According to Samanya \& Yamauchi (2002), increased villus height is paralleled by an increased digestive and absorptive function of the intestine due to the increased absorptive surface area, the expression of brush border enzymes, and the nutrient transport systems.

In fact, growth promoters are able to modify the morphology of the small intestine. This could be attributed to the fact that the promoters reduce the growth of many pathogenic or nonpathogenic intestinal organisms. The reduction of the inflammatory reactions at the intestinal mucosa leads to the increase of the villus area and of the functions of secretion, digestion, and absorption of nutrients by the mucosa (Miles et al., 2006).

Although there were a few controversial reports regarding the safety of black pepper or piperine as food additives (Srinivasan, 2007), the examination of the proventriculus, gizzard, liver, kidney, and small

Table 4. Surface absorption in small intestine of chicken broiler fed diets supplemented with different concentrations of piperine ${ }^{(1)}$.

\begin{tabular}{|c|c|c|c|c|c|}
\hline \multirow[t]{2}{*}{ Fragment of small intestine } & \multicolumn{4}{|c|}{ Piperine $\left(\mathrm{mg} \mathrm{kg}^{-1}\right)$} & \multirow{2}{*}{$\begin{array}{l}\text { CV } \\
(\%)\end{array}$} \\
\hline & 0 & 60 & 120 & 180 & \\
\hline \multicolumn{6}{|l|}{ Duodenum } \\
\hline Villi height $(\mu \mathrm{m})$ & $1,344 \pm 151.70 \mathrm{a}$ & $1,323 \pm 189.30 \mathrm{a}$ & $1,350 \pm 288.20 \mathrm{a}$ & $1,304 \pm 194.20 \mathrm{a}$ & 15.36 \\
\hline Villi width $(\mu \mathrm{m})$ & $190.00 \pm 45.70 \mathrm{a}$ & $229.20 \pm 52.56 b$ & $198.60 \pm 70.05 \mathrm{a}$ & $203.70 \pm 62.71 \mathrm{a}$ & 28.26 \\
\hline Crypt depth $(\mu \mathrm{m})$ & $416.90 \pm 86.89 \mathrm{a}$ & $332.40 \pm 94.94 b$ & $317.10 \pm 64.52 \mathrm{c}$ & $356.40 \pm 96.03 \mathrm{bc}$ & 19.03 \\
\hline Surface absorption $\left(\mathrm{mm}^{2}\right)$ & $0.25 \pm 0.06 \mathrm{a}$ & $0.32 \pm 0.09 \mathrm{~b}$ & $0.29 \pm 0.10 \mathrm{a}$ & $0.29 \pm 0.11 \mathrm{a}$ & 24.46 \\
\hline \multicolumn{6}{|l|}{ Jejune } \\
\hline Villi height $(\mu \mathrm{m})$ & $1,738 \pm 230.80 \mathrm{a}$ & $1,024 \pm 140.80 \mathrm{~b}$ & $1,092 \pm 138.40 \mathrm{~b}$ & $1,012 \pm 138.40 \mathrm{~b}$ & 15.68 \\
\hline Villi width $(\mu \mathrm{m})$ & $160.20 \pm 44.55 \mathrm{a}$ & $179.10 \pm 39.68 \mathrm{a}$ & $161.30 \pm 43.30 \mathrm{a}$ & $145.70 \pm 41.04 \mathrm{a}$ & 26.04 \\
\hline Crypt depth $(\mu \mathrm{m})$ & $234.00 \pm 47.54 \mathrm{a}$ & $218.40 \pm 21.93 \mathrm{ab}$ & $168.60 \pm 34.71 \mathrm{~b}$ & $196.20 \pm 29.09 \mathrm{~b}$ & 19.07 \\
\hline Surface absorption $\left(\mathrm{mm}^{2}\right)$ & $0.24 \pm 0.04 \mathrm{a}$ & $0.21 \pm 0.34 \mathrm{a}$ & $0.17 \pm 0.04 \mathrm{~b}$ & $0.15 \pm 0.03 b$ & 20.02 \\
\hline \multicolumn{6}{|l|}{ Ileum } \\
\hline Villi height $(\mu \mathrm{m})$ & $523.10 \pm 120.50 \mathrm{a}$ & $752.90 \pm 114.0 \mathrm{~b}$ & $909.00 \pm 155.30 \mathrm{c}$ & $755.10 \pm 73.84 b$ & 16.26 \\
\hline Villi width $(\mu \mathrm{m})$ & $129.50 \pm 37.13 \mathrm{a}$ & $144.10 \pm 42.23 b$ & $168.30 \pm 49.97 b$ & $111.10 \pm 32.97 \mathrm{a}$ & 28.92 \\
\hline Crypt depth $(\mu \mathrm{m})$ & $127.70 \pm 36.18 \mathrm{a}$ & $181.30 \pm 40.04 \mathrm{~b}$ & $246.10 \pm 60.83 \mathrm{c}$ & $175.50 \pm 55.80 \mathrm{~b}$ & 26.27 \\
\hline Surface absorption $\left(\mathrm{mm}^{2}\right)$ & $0.06 \pm 0.02 \mathrm{a}$ & $0.12 \pm 0,03 b$ & $0.16 \pm 0.06 \mathrm{~b}$ & $0.08 \pm 0.02 \mathrm{a}$ & 29.03 \\
\hline
\end{tabular}


intestine did not indicate any alterations in the size and the color of the parenchyma and the mucosa of organs or the presence of lesions when different piperine doses were added to the feed. However, mononuclear infiltration was observed in the hepatic tissue (Figure 1), randomly disposed forming nodules with
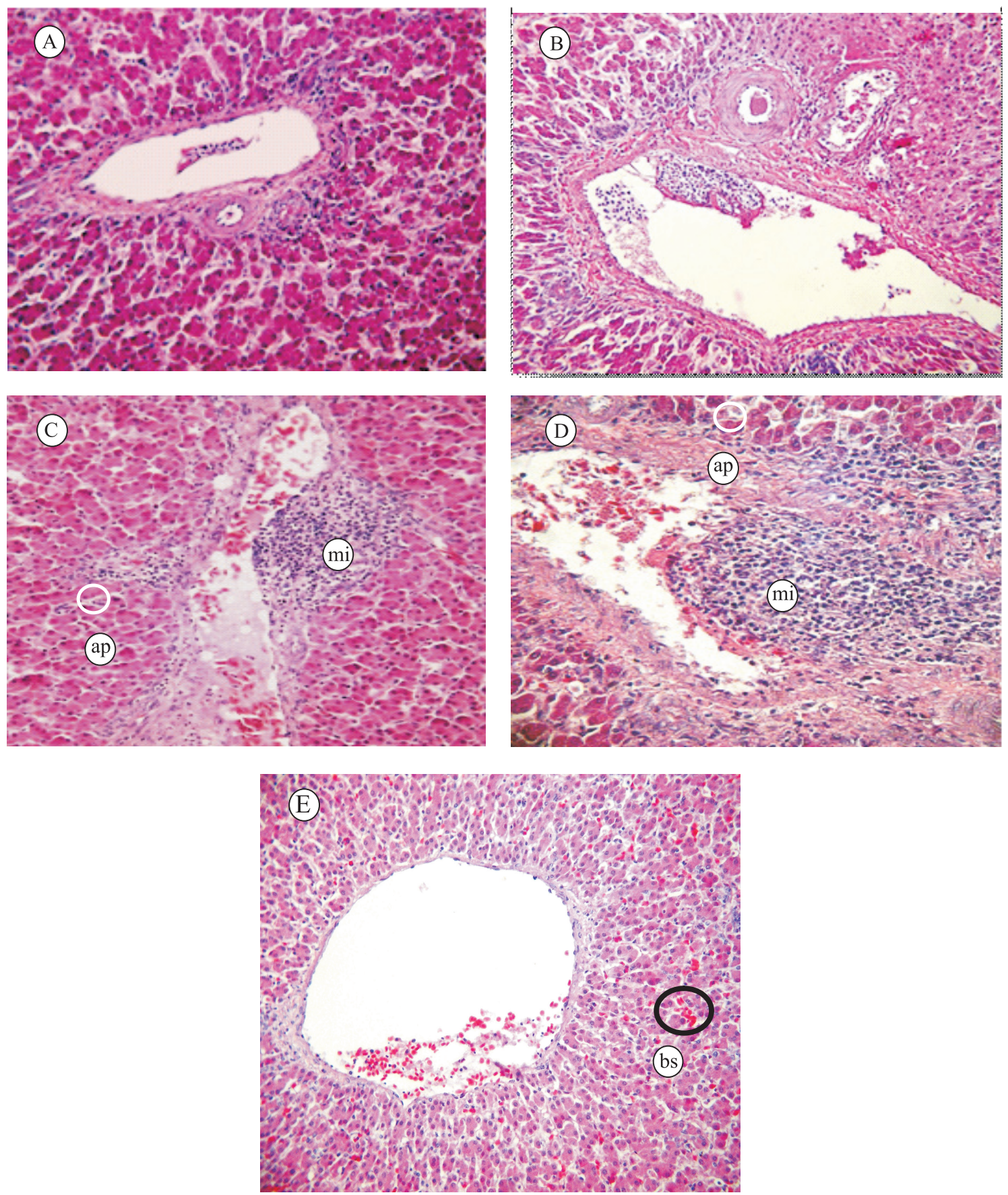

Figure 1. Sections of hepatic tissue of chicken broiler fed diets supplemented with different concentrations of piperine, stained with haematoxylin and eosin, and examined by an optical microscope (Olympus CH30), at $200 \mathrm{x}$, coupled with a Nikon digital camera (Coolpix 4300). A, control $0 \mathrm{mg} \mathrm{kg}^{-1}$ of piperine; B, C, and D, concentrations of 60, 120, and $180 \mathrm{mg} \mathrm{kg}^{-1}$ of piperine, respectively; E, $180 \mathrm{mg} \mathrm{kg}^{-1}$ of piperine, showing dilatation of blood sinusoids (bs). Mononuclear infiltration (mi) randomly disposed forming nodules, and hepatocytes showing small dense nuclei - apoptosis process (ap) - near the portal space at 120 and $180 \mathrm{mg} \mathrm{kg}^{-1}$ of piperine. 
predominance of macrophages and rare heterophils near the portal space, with dose-dependent characteristics. The sinusoids in the control and in the treatments with $60 \mathrm{mg} \mathrm{kg}^{-1}$ of piperine showed almost normal architecture, although there was a dilatation of blood sinusoids in the broiler fed diets with $180 \mathrm{mg} \mathrm{kg}^{-1}$ of piperine. In addition, many hepatocytes showed small dense nuclei (apoptosis process) near the portal space, at 120 and $180 \mathrm{mg} \mathrm{kg}^{-1}$.

\section{Conclusions}

1. The supplementation of $60 \mathrm{mg} \mathrm{kg}^{-1}$ of piperine in broiler diet increases weight gain and feed conversion rate at 36 to 42 days of age, and significantly increases the absorption surface in the duodenum and the ileum.

2. The concentration of $180 \mathrm{mg} \mathrm{kg}^{-1}$ of piperine is toxic to leukocytes, promoting leucopenia, whereas the decrease of monocytes is observed in all concentrations of piperine and is dose-dependent.

3. The supplementation of 120 and $180 \mathrm{mg} \mathrm{kg}^{-1}$ of piperine is toxic to liver tissue and reduces the absorption surface of the jejune.

4. The diet supplemented with $60 \mathrm{mg} \mathrm{kg}^{-1}$ of piperine is secure.

\section{Acknowledgements}

To Conselho Nacional de Desenvolvimento Científico e Tecnológico, for financial support and for scholarship granted; and to Dr. Maria Glória Direito from the Mycotoxicology Laboratory of the Veterinary Institute of the Universidade Federal do Rio de Janeiro, $\mathrm{RJ}$, Brazil, for mycotoxin analysis in the corn used in the feeds.

\section{References}

ARAÚJO-JÚNIOR, J.X.; CUNHA, E.V.L. da; CHAVES, M.C.; GRAY, A.I. Piperdardina, a piperidine alkaloid from Piper tuberculatum. Phytochemistry, v.44, p.559-561, 1997.

BAJAD, S.; BEDI, K.L.; SINGLA, A.K.; JOHRI, R.K. Antidiarrhoeal activity of piperine in mice. Planta Medica, v.67, p.284-287, 2001.

BHAT, B.G.; CHANDRASEKHARA, N. Studies on the metabolism of piperine: absorption, tissue, distribution and excretion of urinary conjugates in rats. Toxicology, v.40, p.83-92, 1986.

BOTSOGLOU, N.A.; FLOROU-PANERI, P.; CHRISTAKI, E.; FLETOURIS, D.J.; SPAIS, A.B. Effect of dietary oregano essential oil on performance of chickens and on iron-induced lipid oxidation of breast, thigh and abdominal fat tissues. British Poultry Science, v.43, p.223-230, 2002.

CAMPBELL, T.W.; DEIN, F.J. Avian hematology: the basics. Veterinary Clinics of North America: Small Animal Practice, v.14, p.223-248, 1984.

CARDOSO, V. da S.; LIMA, C.A.R. de; LIMA, M.E.F.; DORNELES, L.E.G.; TEIXEIRA FILHO, W.L.; LISBOA, R.S.; GUEDES JUNIOR, D.S.; DIREITO, G.M.; DANELLI, M. das G.M. Administração oral de piperina em frangos de corte. Ciência Rural, v.39, p.1521-1526, 2009.

CASTANON, J.I.R. History of the use of antibiotic as growth promoters in European poultry feeds. Poultry Science, v.86, p.2466-2471, 2007.

COLES, E.H. Patologia clínica veterinária. 3.ed. São Paulo: Manole, 1984. 566p.

CROSS, D.E.; MCDEVITT, R.M.; HILLMANM K.; ACAMOVIC, T. The effect of herbs and their associated essential oils on performance, dietary digestibility and gut microflora in chickens from 7 to 28 days of age. British Poultry Science, v.48, p.496-506, 2007.

DOGRA, R.K.S.; KHANNA, S.; SHANKER, R. Immunotoxicological effects of piperine in mice. Toxicology, v.196, p.229-236, 2004.

ERTAS, O.N.; GÜLER, T.; ÇIFTÇI, M.; DALKILIÇ, B.; SIMSEK, Ü.G. The effect of an essential oil mix derived from oregano, clove and anise on broiler performance. International Journal of Poultry Science, v.4, p.879-884, 2005.

GAGINI, T.B.; SILVA, R.E.; CASTRO, I.S.; SOARES, B.A.; LIMA, M.E.F.; BRITO, M.F.; MAZUR, C.; DIREITO, G.M.; DANELLI, M.G.M. Oral administration of piperine for the control of aflatoxin intoxication in rats. Brazilian Journal of Microbiology, v.41, p.345-348, 2010.

IKAN, R. Natural products: a laboratory guide. 2.ed. New York: Academic, 1991. 316p.

JAIN, N.C. Essential of veterinary hematology. Philadelphia: Lea and Febiger: 1993. 417p.

KANEKO, J.J. Appendixes. In: KANEKO, J.J. Clinical biochemistry of domestic animals. 4.ed. San Diego: Academic Press, 1989. p.877-901.

KARAN, R.S.; BHARGAVA, V.K.; GARG, S.K. Effect of trikatu, an Ayurvedic prescription, on the pharmacokinetic profile of rifampicin in rabbits. Journal of Ethnopharmacology, v.64, p.259-264, 1999.

KHAJURIA, A.; THUSU, N.; ZUTSHI, U. Piperine modulates permeability characteristics of intestine by inducing alterations in membrane dynamics: influence on brush border membrane fluidity, ultrastructure and enzyme kinetics. Phytomedicine, v.9, p.224-231, 2002.

KOHLERT, C.; VAN RENSEN, I.; MÄRZ, R.; SCHINDLER, G.; GRAEFE, E.U.; VEIT, M. Bioavailability and pharmacokinetics of natural volatile terpenes in animals and humans. Planta Médica, v.66, p.495-505, 2000. 
MILES, R.D.; BUTCHER, G.D.; HENRY, P.R.; LITTELL, R.C. Effect of antibiotic growth promoters on broiler performance, intestinal growth parameters, and quantitative morphology. Poultry Science, v.85, p.476-485, 2006.

MITTAL, R.; GUPTA, R.L. In vitro antioxidant activity of piperine. Methods and Findings in Experimental and Clinical Pharmacology, v.122, p.271-274, 2000.

OCAK, N.; ERENER, G.; BURAK, A.K.F.; SUNGU, M.; ALTOP, A.; OZMEN, A. Performance of broilers fed diets supplemented with dry peppermint (Mentha piperita L.) or thyme (Thymus vulgaris L.) leaves as growth promoter source. Czech Journal of Animal Science, v.53, p.69-175, 2008.

PERIĆ, L.; ŽIKIĆ, D.; LUKIĆ, M. Application of alternative growth promoters in broiler production. Biotechnology in Animal Husbandry, v.25, p.387-397, 2009.

PRADEEP, C.R.; KUTTAN, G. Piperine is a potent inhibitor of nuclear factor-kB (NF-kB), c-Fos, CREB, ATF-2 and pro-inflammatory cytokine gene expression in B16F-10 melanoma cells. International Immunopharmacology, v.4, p.1795-1803, 2004.

REDDY, S.V.; SRINIVAS, P.V.; PRAVEEN, B.; KISHORE, K.H.; RAJU, B.C.; MURTHY, U.S.; RAO, J.M. Antibacterial constituents from the berries of Piper nigrum. Phytomedicine, v.11, p.697-700, 2004.

REEN, R.K.; WIEBEL, F.J.; SINGH, J. Piperine inhibits aflatoxin B1-induced cytotoxicity and genotoxicity in V79 Chinese hamster cells genetically engineered to express rat cytochrome P4502B1. Journal of Ethnopharmacology, v.58, p.165-173, 1997.

ROSTAGNO, H.S.; ALBINO, L.F.T.; DONZELE, J.L.; GOMES, P.C.; OLIVEIRA, R.F. de; LOPES, D.C.; FERREIRA, A.S.;
BARRETO, S.L.T. de. Tabelas brasileiras para aves e suínos: composição de alimentos e exigências nutricionais. 2.ed. Viçosa: UFV, 2005. 186p.

SAMANYA, M.; YAMAUCHI, K. E. Histological alterations of intestinal villi in chickens fed dried Bacillus subtilis var. natto. Comparative Biochemistry and Physiology Part A: Molecular and Integrative Physiology, v.133, p.95-104, 2002.

SCHEUERMANN, G.N.; CUNHA JUNIOR, A.; CYPRIANO, L.; GABBI, A.M. Phytogenic additive as an alternative to growth promoters in broiler chickens. Ciência Rural, v.39, p.522-527, 2009.

SCHMIDT, E.M.S.; LOCATELLI-DITTRICH, R.; SANTIN, E.; PAULILLO, A.C. Patologia clínica em aves de produção - uma ferramenta para monitorar a sanidade avícola - revisão. Archives of Veterinary Science, v.12, p.9-20, 2007.

SIDDIQUI, B.S.; BEGUM, S.; GULZAR, T.; NOOR, F. An amide from fruits of Piper nigrum. Phytochemistry, v.45, p.1617-1619, 1997.

SINGH, Y.N. Kava: an overview. Journal of Ethnopharmacology, v.37, p.13-45, 1992.

SRINIVASAN, K. Black pepper and its pungent principle-piperine: a review of diverse physiological effects. Critical Reviews in Food Science and Nutrition, v.47, p.735-748, 2007.

TAKAKI, M.; JIN, J.G.; LU, Y.F.; NAKAYAMA, S. Effects of piperine on the motility of the isolated guinea-pig ileum: comparison with capsaicin. European Journal of Pharmacology, v.186, p.71-77, 1990.

TROBE, M.M. Variations on the size and haemoglobin content of erythrocytes in the blood of various vertebrates. Folia Haematologica, v.51, p.32-49, 1934.

Received on September 21, 2011 and accepted on February 4, 2012 